\title{
A Natureza e a gênese das Minas do Sul nos livros de André João Antonil e Sebastião da Rocha Pita
}

Francisco Eduardo de Andrade

UFMG

\section{RESUMO}

Este artigo trata do sentido cosmológico da Natureza, em voga na época das representações do barroco (séculos XVII e XVIII), quando aplicado ao contexto novo da América portuguesa com o descobrimento das Minas de ouro. Dois autores da Bahia foram significativos das primeiras visões de Natureza e da sociedade das Minas do ouro: André João Antonil e Sebastião da Rocha Pita. Ambos produziram obras sobre a gênese do espaço minerador, buscando, de algum modo, integrá-lo a uma história providencial da colonização portuguesa. Para isso, investiram em temas e imagens que, além de condicionados por evidentes interesses políticos e econômicos dos plantadores do litoral, refletem os vínculos discursivos dos coloniais eruditos. Palavras-chave: Natureza; Minas de ouro; discurso.

\section{ABSTRACT}

This work deals with the cosmological sense of the Nature, which has been intensively studied at the time of baroc representations ( $17^{\text {th }}$ and $18^{\text {th }}$ centuries), applied to the Portuguese America new context of gold mines discoveries. Two authors from Bahia were very important to the early views on the Nature and on the society in gold mines: André João Antonil and Sebastião da Rocha Pita. Both have made studies about the genesis of the mining space in such a way to integrate it in an opportune history of the Portuguese colonization. To do this, they dealed mainly with subjects and images which reveal discourse links of colonial wise persons, and also which were influenced by political and economical interests of the coastal farmers. Keywords: Nature; Gold mines; Discourse.

Nos escritos políticos e teológicos da Europa católica dos séculos XVII e XVIII, particularmente no período em que vigoraram as formas de representação ditas "barrocas", ${ }^{1}$ as manifestações da Natureza inscreviam-se no plano divino da ligação do Criador com os homens. Nessa concepção, consideravase que as coisas da Natureza (ou as suas obras) — desde o céu e a terra até as plantas e os animais - fossem a manifestação do universo criado no tempo primordial, e ainda do seu curso histórico como Providência. ${ }^{2} \mathrm{O}$ mundo natural, então, era um relato da criação providencial de Deus. 
A Natureza desvelava-se numa conjunção de signos que lembravam aos homens a história sagrada da criação. Manifestava-se como o livro de Deus, cuja escritura guardava as significações misteriosas prescritas pela ordem do alto. Com isso, a ordem da Natureza era forçosamente da ordem da razão, e do desvendamento, porque radicava-se na verdade absoluta de Deus.

O meio de perscrutar e compreender tal livro da Natureza e de Deus construía-se através das associações e analogias entre as coisas. Procurava-se compreender, a partir da interpretação dos fatos naturais, o percurso sinuoso, a trajetória da história sagrada confiada aos homens. ${ }^{3}$ Assim, a Natureza assumia uma engenhosa dimensão cosmológica, em que nada era o que parecia à primeira vista. ${ }^{4} \mathrm{O}$ detalhe ou o pequeno podiam fornecer a chave de toda a verdade escondida num mundo feito de correspondências entre o microcosmo e o cosmos. ${ }^{5}$ Daí os desenhos simbólicos que expressavam uma verdade escondida, como o de um mapa alemão de 1581 que figurava o velho mundo — Europa, Ásia, África — na forma de um trevo de três folhas, unidas a um círculo central significando Jerusalém. ${ }^{6}$

Nessa concepção, havia uma arquitetura harmoniosa das coisas e elementos do Universo a indicar e a promover o caminho da redenção futura. Se nada devia ocorrer por acaso no mundo natural, até mesmo as novidades deste mundo convinham aos homens para lembrar o pacto inquebrantável da criação, e da revelação do Cristo. Na América portuguesa, prosaicas bananas podiam ser vistas (num procedimento de pós-figuração) como um fruto adâmico. Fernão Cardim, e Cláudio Manuel da Costa mais de um século depois (1773), utilizaram a metáfora da figueira do Éden para designar a bananeira. ${ }^{7}$ Além disso, os frutos desta, quando cortados, mostravam no centro a imagem de um crucifixo, segundo Pero de Magalhães Gândavo e Gabriel Soares de Souza (1587). ${ }^{8}$ O primeiro, em 1576, a respeito de uma "erva viva" existente na América que ao ser tocada se encolhia e murchava, assinalou:

Esta planta deve ter alguma virtude muito grande, a nós encoberta, cujo efeito não será pela ventura de menos admiração. Porque sabemos de todas as ervas que Deus criou, ter cada uma particular virtude com que fizessem diversas operações naquelas coisas para cuja utilidade foram criadas e quanto mais esta a que a natureza nisto tanto quis assinalar dando-lhe um tão estranho ser e diferente de todas as outras ${ }^{9}$

Também, para uma tradição de escritores barrocos, a flor do maracujá, na sua forma misteriosa, traduzia-se pelos signos da paixão do Cristo (cra- 
vos, coroa, chagas), e o ananás (numa invenção muito engenhosa) podia representar o rosário da Mãe de Deus. ${ }^{10}$ Montanhas, marcos de orientação no sertão ou formações de tesouros minerais, podiam ser figuradas por meio dos sucessos da história do filho de Deus, como a famosa e mítica serra dos Martírios, situada em algum lugar do Planalto central brasileiro. Ao mesmo tempo, o rio São Francisco - com lagoa aurífera na nascente, fantástico sumidouro (aplicado também a outros rios do oriente do Brasil) e estranho regime de águas - chegou a ser identificado como tendo a sua origem no Paraíso terrestre. ${ }^{11}$

De fato, mesmo no século XVIII, embora já houvesse um desencantamento acentuado com aquela ordem misteriosa da Natureza, as imagens cosmológicas das coisas naturais ainda mantinham sua força cognitiva e expressiva entre os colonos. As plantas, os animais, os minerais, as montanhas e os rios, em suma todas as manifestações naturais e geográficas da América, faziam parte do teatro universal da criação. Daí o investimento simbólico dos colonos, e principalmente dos defensores da missão cristã, nas coisas que denunciavam a redenção espiritual e a vida paradisíaca, ou o contrário, a queda e os tormentos do inferno.

Análoga ao mundo natural, a organização social e as instituições políticas obedeciam aos critérios da razão conferida por Deus à ordem universal, da qual não se poderia escapar. Houve assim o enlaçamento entre o natural e o social, uma correlação estreita que tendia à passagem de um campo para o outro. Se a Natureza expressava o concerto do Criador com os homens, a própria sociedade, que resultava da razão inspirada de Deus e compartilhada pelos homens, apresentava-se como da ordem natural.

Decorre disso o método de alegorização da História — história teológica, história natural, história moral —, ou propriamente dos fatos da História, feita por teólogos e tratadistas católicos da época moderna, utilizando uma técnica aguda de interpretação essencial do mundo a partir das "sombras" e dos "vestígios" de Deus representados por seres e pelos acontecimentos terrenos. Particularmente, as escrituras bíblicas — livro de Deus - e os autores da Antiguidade clássica conferiam um modelo de interpretação, os tipos significativos dos acontecimentos históricos futuros. ${ }^{12}$ A retórica (ou discurso) da história faz-se, nesse sentido, como uma narrativa baseada em casos e personagens exemplares selecionados segundo um programa teológico-político de ensinamento moral, ${ }^{13}$ muito embora para a sensibilidade barroca a decifração do mundo presente e passado fosse no mínimo problemática. 
A própria escrita, que representa a fala que reescreve a natureza e a história, torna-se vã, golpeada pela plenitude da absoluta ciência divina sempre além. Assim, convulsiona-se, novelo de enigmas, mantendo sempre certo traço irrisório de detrito e de ruína, vestígios de uma verdade fugidia. Se a natureza mesma é um texto que se decifra e copia - a Contra-Reforma pôs em circulação de novo a interpretação medieval da alegoria factual —, é, contudo, um texto mudo, pois anda afetada do pecado original e veste luto. ${ }^{14}$

Mesmo assim, e por isso mesmo, um padre Antônio Vieira vigilante, na última década do século XVII, ao observar certo cometa que riscou o céu da Bahia o interpretou como a "Voz de Deos" avisando Portugal e a Bahia sobre os tempos conturbados, condição do castigo. Seguindo o procedimento analógico, o padre alertou: "Isto he o que descobre a espada do Ceo, \& (com particular mysterio, e energia) no mesmo tempo de outros descobrimentos; quando imos descobrir os enganos da fama, descobrio nos o Ceo os desenganos da vida; não estão as minas nos cerros, estão no Ceo". ${ }^{15} \mathrm{O}$ descobrimento verdadeiro (da verdade divina), desengano da vaidade, seria o cometa ao revelar sem subterfúgios os pecados coloniais e anunciar os seus temíveis efeitos.

Vieira, gravemente atento à história e aos fatos, compreendeu o movimento celeste e a mudança política no mesmo diapasão teológico. Se expressavam a divina providência (como ser e ações de Deus) na história humana, ambos congregavam para o descobrimento interpretativo de uma verdade plena. Nessa medida, o próprio Estado cristão e português, visto como vontade comum do povo e eleição divina, era uma "forma encoberta" e espécie sacramental de redenção humana (natural) e política. ${ }^{16}$

A esse Estado único [instituto da nação portuguesa] cabe, para Vieira, segundo a escolha divina sacramentada na sucessão dinástica [que remonta a Afonso Henriques], ser causa segunda eficaz da harmonização entre os movimentos heteróclitos da Terra e os desígnios da divina Lei, ser agente humano da atualização da semelhança entre o mundo criado e sua Causa Primeira. ${ }^{17}$

Contudo, segue-se que a luz da razão natural (ou a vontade de Ser), segundo a Providência de Deus, não esgotava as ações humanas ou os percursos da vida social; ao contrário, o princípio do arbítrio humano conduzia à escolha do vício ou da virtude. Daí o programa de reforma moral e política, segundo uma teoria da atividade sistemática do Estado, que tendeu a julgar não só as instituições e práticas sociais, mas a recobrir, ao mesmo tempo, as 
representações da Natureza. Nesta perspectiva, a ambiência natural e a vida social, perfiladas, eram compreendidas segundo esquemas de pensamento e de análise semelhantes.

\section{DEsCRIÇÃo DA NATUREZA NAS Minas do OURO}

Em 1656, no sermão da Primeira Oitava de Páscoa pregado na Matriz de Belém, Antônio Vieira procurou explicar o fracasso do descobrimento de minas de ouro na capitania do Grão-Pará. Nesse discurso, a representação uma alegoria factual reveladora da verdade última — das minas de minerais preciosos apresentava uma feição bem acabada. ${ }^{18}$ As minas já possuíam uma espécie de defeito congênito, pois os minerais não apareceram no programa de criação divina estabelecido para a utilidade dos homens. Os metais preciosos não foram direta nem explicitamente mencionados no livro da Criação (o Gênesis bíblico). Deus acabou guardando silêncio sobre eles, mantendo-os escondidos nas entranhas da terra, e isso devia mostrar aos colonos cristãos a necessidade de saber evitá-los. O verdadeiramente legítimo do ponto de vista da lei divina seria cuidar da agricultura, valorizando o que a terra produzisse na superfície.

Nessa concepção, a Natureza do lugar de minas apresentava-se perigosa, demoníaca: estéril, montanhosa, penhascosa, repleta de buracos infernais da mineração. Assim, para Vieira, "A água no seu centro não pesa; o fogo na sua esfera não queima; a terra, se sobe ao ar, faz raios; o ar, se se mete debaixo da terra, faz terremotos, derruba casas e cidades: assim também o ouro e prata das minas". Uma ordem natural alterada, um “incidente", que se apartava da razão revelada e da verdade. ${ }^{19}$ Os tesouros minerais comunicavam, atiçavam vícios; o pior deles: a cobiça. Seguia-se o desregramento moral dos exploradores, assim como a penúria e a opressão fiscal e política. Vieira, no sermão das minas, fez um paralelo entre uma exploração colonial irracional (como o das jazidas minerais), que parecia potencializar o aspecto incidental da Natureza, e a queda dos colonos numa situação (infernal) de vícios e imoralidades. As minas e seus descobrimentos eram castigos escondidos de Deus que depois se manifestam em fomes, pestes, guerras "e outras calamidades temporais”. Castigos mais terríveis porque sob aparência enganadora da imagem preciosa que os homens (e os colonos) tanto estimavam.

Se a Natureza das minas tinha seus erros ou causas acidentais que convergiam para a vida social, tornava-se imprescindível um programa de refor- 
ma moral para atenuar pelo menos aqueles temíveis efeitos. Por isso, com o descobrimento das Minas gerais do ouro no interior da América portuguesa, desde os primeiros anos da década de 1690, não podia deixar de ocorrer a interpretação e análise do curso dos acontecimentos a partir do repertório tradicional de representações coletivas - além de discursivas — que Vieira bem expressou no sermão de 1656. Com efeito, os dois primeiros relatos publicados sobre as Minas, ainda sob o impacto das notícias das riquezas das jazidas descobertas, revelam a mesma composição vieiriana, tornada canônica, mas, é certo, sob a luz de um outro contexto histórico. Esses relatos ou histórias breves das Minas do ouro apareceram em duas obras do início do século XVIII: Cultura e opulência do Brasil por suas drogas e minas, de André João Antonil (pseudônimo de João Antônio Andreoni), publicada em 1711, e História da América portuguesa, de Sebastião da Rocha Pita, cuja primeira edição surgiu em 1730. O valor desses livros para a história colonial brasileira é incontestável. No entanto, quando a historiografia utiliza-os, especialmente o primeiro, em virtude de sua suposta maior isenção, como fonte de informações fidedignas sobre a gênese das Minas, deve-se averiguar não somente as condições concretas de fabricação dos textos, mas também avaliar a estratégia de "eficácia performativa do discurso" conferida pela exposição/descrição. ${ }^{20}$

Usualmente apreendidos como fontes privilegiadas de dados e informações sobre a história da fundação dos núcleos de mineração, nesses textos subsistem, no entanto, representações, conceitos e valores carregados evidentemente de comprometimento social e político. Tais conjunções simbólicas permitem outrossim revelar, naqueles testemunhos coevos, como diriam os historiadores, de Antonil e de Rocha Pita, a raiz performativa do discurso o poder de visão e de divisão do mundo natural e social —, que se inscreve num campo prestigioso do saber: o teológico ou religioso. ${ }^{21}$

Portanto, buscar-se-á conferir nas obras de gênese - as primeiras em inserir as Minas no processo social, político e econômico da história da colonização lusa da América - a manobra performativa dos relatos sobre os descobertos minerais e a região das Minas, quando tratam da Natureza e a sua conjunção com as representações sociais e políticas.

O padre jesuíta João Antônio Andreoni, originário da Toscana, era formado em direito, tendo permanecido no Brasil até a sua morte, durante 35 anos. Exerceu aqui as funções de secretário do padre Visitador geral Antônio Vieira e de alguns Provinciais, e de Visitador local de Pernambuco enviado por Vieira em 1689. Mantendo-se no serviço da Companhia de Jesus, foi pregador, professor de retórica, diretor da congregação dos estudantes, mestre 
de noviços, Reitor do Colégio da Bahia, Provincial e confessor de dois governadores gerais, o marquês das Minas e D. João de Lencastre. ${ }^{22}$ Entre os seus comentadores críticos, houve quem afirmasse que o padre Andreoni esteve em São Paulo no início da década de 1690 como secretário do vice-provincial nas negociações da Companhia com os senhores paulistas sobre a liberdade indígena, mas Andrée Mansuy Diniz Silva, numa investigação aprofundada, contesta essa informação. ${ }^{23}$

No Cultura e opulência, o texto mais importante atribuído ao padre Andreoni, observa-se um ordenamento desigual das partes escritas, predominando na exposição das formas econômicas coloniais a produção açucareira. Seguem-se a lavoura e produção do tabaco, as minas de ouro, e a pecuária conjugada com a fabricação de couros ou solas. Andrée Mansuy conferiu o tamanho do desenvolvimento dos temas: o do açúcar foi tratado em três livros, cada um com 12 capítulos; o do tabaco constitui-se somente de 12 capítulos (20 páginas no total); o das minas corresponde a 17 capítulos (52 páginas) e o da pecuária compreende somente quatro capítulos (excluindo-se os dois últimos capítulos, um sobre os valores anuais dos principais produtos exportados, e outro assinalando a justiça das pretensões de prestígio político e social dos senhores de engenho e lavradores de cana e de tabaco).$^{24}$ De certa forma coerente com tal descuido demonstrado no texto sobre o gado bovino, gênero indispensável do abastecimento interno, é notável, mas compreensível na perspectiva do colonialismo mercantilista predominante entre os promotores do Estado, como explicou Alice Canabrava, a ausência de qualquer avaliação sobre a produção e as potencialidades das lavouras de subsistência (até mesmo sobre a produção de farinha de mandioca, mercadoria importante no trato com a África e essencial no abastecimento das frotas).$^{25}$

As partes temáticas que compõem o livro, especialmente a relacionada às minas de ouro, não parecem obedecer à motivação inicial do texto principal - o que trata da "lavra do assucar". Andrée Mansuy, observando a falta de harmonia na composição da obra, o prefácio estranhamente referido somente à primeira parte (a do açúcar), o estilo prestigioso — lapidado com metáforas ou analogias barrocas - do texto dessa parte, levanta a hipótese convincente de que Antonil pretendesse inicialmente tratar somente da atividade açucareira. Corroboram isso os indícios (preços, nomes de pessoas, acontecimentos) e as datas constantes nos capítulos do livro, apontando momentos diferenciados da escrita. Tudo indica que a atenção às outras atividades foi surgindo com o tempo, quando possivelmente a primeira parte já havia sido escrita — provavelmente entre 1693 e 1698 — , e assim mais capítulos 
foram incorporados à obra - escritos entre 1707 e 1709. O capítulo final, de caráter conclusivo, efetivamente dava atenção especial aos agentes da lavra açucareira, outro indício sugestivo do plano inicial de um livro de "economia rústica" (administração de unidades agrárias). ${ }^{26}$ Nele Antonil exortou a Coroa portuguesa a olhar com inteira liberalidade para os súditos fiéis e úteis (à fazenda real e ao bem comum) como eram os senhores de engenho e os lavradores de cana e de tabaco, concedendo-lhes despachos favoráveis, mercês e funções proeminentes do Estado. ${ }^{27}$

Mas como Antonil buscou integrar as Minas do ouro, cujo rumor noticioso atraía os coloniais para o sertão das capitanias do Sul, no esquema renovado da pauta de interesses metropolitanos? E quanto aos agentes dos descobrimentos minerais, como participavam do jogo colonial?

Embora tivesse se oposto ao padre Vieira em questões de doutrina e de prática relativas à liberdade dos índios, há indicações suficientes em Cultura e opulência de adesão fundamental à concepção teológica detratora das minas, bem expressada por Vieira no citado sermão. ${ }^{28} \mathrm{No}(\mathrm{s})$ livro(s), o sentido geral visava prestigiar a açucarocracia colonial — baiana em particular —, com a qual convivia na cidade da Bahia e da qual dependia por seus legados ou doações para os serviços missionários da Companhia de Jesus (no caso específico, pedir para que os senhores de grandes lavouras e de minas contribuíssem com esmolas para as despesas do processo de canonização do padre Anchieta, então em curso). Ele conferiu à colonização lusa e à política de Estado no Brasil a capacidade de conduzir de modo moralmente legítimo a ambiência natural e social, ou seja, as formas econômicas coloniais. As Minas do ouro, que haviam sido fabricadas com o amparo do Estado, não eram um mal a ser evitado a qualquer custo, como chegou a propor o padre Vieira, mas um mal a ser controlado, governado pelos súditos poderosos e pela Coroa, convergindo-se para os núcleos legítimos do Poder. A subordinação política e econômica das Minas e dos novos habitantes às necessidades da açucarocracia é o que ele sugeriu, valendo-se das formas tradicionais de representação das minas (dos minerais preciosos) e da condição dos seus exploradores. Antonil reproduz o que a Câmara de Salvador e os governadores gerais costumavam afirmar na primeira década do século XVIII: a fabricação do açúcar e a cultura do tabaco "eram as verdadeiras minas do Brasil e de Portugal". Depois do descobrimento das Minas, providência divina no curso da história, a extração do ouro castigava o Brasil, "assim como está castigando no mesmo tempo tão abundante de guerras aos Europeus com o ferro". ${ }^{29}$ De fato, para Antonil o Brasil relevante era basicamente o do açúcar, e para este o contexto 
econômico e político dos anos finais da década de 1700 era realmente desalentador: aconteciam novos conflitos armados entre as potências européias, invasões de territórios lusos na América, a retomada da tendência de queda no preço do açúcar e a elevação do preço do escravo africano (concorrência antilhana e dificuldades comerciais no mercado europeu), a pressão inflacionária sobre os preços de gêneros e de escravos promovida pelo fluxo aurífero, e os embates de jurisdição e de interesses entre os baianos/reinóis e os paulistas nas Minas..$^{30}$

Portanto, a descrição factual das Minas feita por Antonil requer a consideração de que ao autor convinha harmonizar as peças políticas e econômicas que comporiam o quebra-cabeça colonial luso-brasileiro, mas de acordo com o ordenamento da açucarocracia.

Para Antonil toda a empresa colonial — arte dos coloniais combinada a uma Natureza prodigiosa —, notadamente a do açúcar, guardava expressivamente analogia com o purgatório cristão. É uma acepção tradicional e tópico da colonização. "E1 "É reparo singular dos que contemplam as coisas naturais ver que as que são de maior proveito ao género humano não se reduzem à sua perfeição sem passarem primeiro por notáveis apertos". ${ }^{32}$

No caso das Minas do ouro, para corrigir a sua vocação infernal e assim chegar a teatro do purgatório, como toda a ambiência colonial (ou colonizada) que conduzia à remissão, seria preciso corrigir o curso dos vícios que grassavam nos descobertos. A economia moral de Antonil ensinava os seus leitores (tanto os senhores lavradores e de minas quanto os representantes régios) a despender suas fortunas com os agentes da Igreja e os administradores (além de mantenedores) do corpo político do Estado para se continuar na posse correspondente de prestígio e poder. O enquadramento do livro supõe a "opulência” - abundância dos meios de prover ou despender — originária das produções coloniais, para manter a circulação de benefícios/prestações entre os produtores e mercadores (lucros), o Estado (emolumentos) e a Coroa (concessões de funções públicas, incluindo-se as eclesiásticas). Os lucros familiares dos coloniais, portanto, justificam-se pelo propósito maior de engrandecimento do corpo político do Estado e da monarquia portuguesa. Daí a crítica latente à riqueza/acumulação cobiçosa de governantes como Artur de Sá e Menezes (o governador da Repartição Sul que esteve nos descobertos três vezes) ou do superintendente das Minas Gerais (ou de Cataguás) José Vaz Pinto, e ainda de senhores enriquecidos preocupados com ganhos próprios nos descobertos do ouro. ${ }^{33}$

Somente a "sede insaciável do ouro" (a cobiça e a vaidade como os males 
típicos de mineiros era noção comum na época) motivou tanta gente "a deixarem suas terras e a meterem-se por caminhos tão ásperos como são os das Minas". Daí a denúncia de que a "mistura é de toda a condição de pessoas", sem hierarquias definidas ou funções determinadas. Na realidade, expressava uma anti-sociedade. Para pôr ordem seria preciso então a (re)forma social e espiritual através da repressão estatal (ou dos governos régio e eclesiástico) aos crimes e pecados dos colonos mineradores, exercendo uma força reparadora - penitencial — do mal necessário que eram as Minas do ouro. ${ }^{34}$ Revela-se assim o sentido do trabalho missionário jesuíta e cristão: a necessária sujeição da cobiça humana, vício corrente no país das Minas, aos limites das autoridades civis e religiosas. ${ }^{35}$ Ainda, e de acordo com concepções cristãs medievais, a condição montanhosa, servindo de recôndito dos pecados e demônios, demarcava a dimensão heróica e santa do feito humano reformador. ${ }^{36}$

A correlação entre uma Natureza áspera ou a condição rústica da vida e a sociedade viciosa, no Cultura e opulência, não deixa realmente de explicar o castigo inevitável dos coloniais na forma da extração mineral. Isso ocorre na crítica de Antonil aos preços dos gêneros e ao abastecimento nos descobertos dos sertões da América. Deve-se assinalar, a propósito, que os historiadores costumam tomar tal relato crítico sobre os preços nas Minas como uma descrição objetiva no qual fundam as suas interpretações sobre os desequilíbrios sociais e econômicos na Colônia da idade do ouro. ${ }^{37}$

Nas rotas de Minas, as serras — verdadeiros obstáculos ou fronteiras que simbolizavam os trabalhos e sacrifícios das terras minerais - interpunhamse aos entrantes. Na entrada do caminho dos paulistas, Antonil indicou que as primeiras cinco serras a serem transpostas "parecem os primeiros muros que o ouro tem no caminho para que não cheguem lá os mineiros”. O quadro montanhoso, superposto à cobiça dos coloniais das Minas, conduz a descrição de Antonil sobre o trato mercantil a partir da serra da Mantiqueira, na rota da Vila de São Paulo (o núcleo principal dos senhores que mantinham autoridade sobre as Minas). Dando notícia dos altos preços dos gêneros das roças dos descobridores, no caminho, Antonil observou que aproveitavam da necessidade dos entrantes, "E daí vem o dizerem que todo o que passou a serra de Amantiqueira aí deixou dependurada ou sepultada a consciência". ${ }^{8}$ Retomava-se assim, num novo espaço geográfico, a sentença corrente na Europa do século XVII que denunciava que abaixo do Equador não se peca, ou seja, nos trópicos os vícios e o relaxamento moral determinam o modo de viver. ${ }^{39}$ Era, como ainda se supunha no século XVIII, a tônica dos costumes em colônias. ${ }^{40}$ 
Antonil nunca estivera no país das Minas, mas seria categórico sobre a sua Natureza (numa passagem bastante citada por historiadores):

Sendo a terra que dá ouro esterilíssima de tudo o que se há mister para a vida humana, e não menos estéril a maior parte dos caminhos das Minas, não se pode crer o que padeceram ao princípio os mineiros por falta de mantimentos, achando-se não poucos mortos com uma espiga de milho na mão, sem terem outro sustento. ${ }^{41}$

O seu informante sobre as técnicas de mineração, acompanhando o governador Artur de Sá e Menezes nas suas entradas, confirmaria a rusticidade singular da paisagem:

em todas as minas que vi e em que assisti, notei que as terras são montuosas, com serros e montes que se vão às nuvens, por cujos centros, correndo ribeiros de bastante água ou córregos mais pequenos, cercados todos de arvoredo grande e pequeno, em todos esses ribeiros pinta ouro com mais ou menos abundância. ${ }^{42}$

A fome dos moradores e a especulação mercantil vieram determinadas por essa Natureza hostil e inculta, aliada à situação moral corrompida. Expressão marcante da relação entre as condições naturais e sociais era a intensidade das práticas mercantis, foco de pecado, que se observava entre os moradores de todas as camadas sociais. Dos homens mais poderosos aos escravos e índios catadores de ouro, dos vendeiros às negras cozinheiras e mulatas de tabuleiro, todos partilhavam "dessa mina à flor da terra" representada por um vigoroso mercado de "superfluidades". ${ }^{33}$

Revela-se, na descrição da esterilidade, o aviso vieiriano sobre as agruras do modus vivendi dos colonos com as minas e os descobrimentos de minerais preciosos. O castigo ao transe cobiçoso dos mineradores veio na pior forma: fome, favorecendo, como seu corolário, os negócios de especulação com a necessidade premente dos moradores. Vieira já havia assinalado esse castigo apocalíptico.

Antonil salientou tal abuso, ou pecado que castigava as gentes, apontando que os preços de gêneros coloniais e europeus mandados para as Minas proporcionavam "lucro não somente grande mas excessivo" para os negociantes e intermediários monopolistas. A lista dos preços praticados nas Minas e estampada pelo jesuíta transparecia mais como denúncia da prática "dos preços extraordinariamente altos", um atentado à lei e à moral que merecia ple- 
na correção por parte do governo e das missões da Igreja. ${ }^{44}$ Preocupa-o, outrossim, que os excessos ("depois de descobertas as minas de ouro que serviram para enriquecer a poucos e para destruir a muitos") repercutam nos preços de escravos e dos recursos necessários aos engenhos das capitanias litorâneas, reproduzindo o temor dos governantes, muitas vezes afetado, de que todo o Brasil se perderia caso arruinasse o principal sustento colonial. ${ }^{45}$ Na realidade, o jesuíta italiano não deixa de conduzir a sua interpretação detratora por outro tópico dos discursos moralizantes sobre a riqueza fugaz, exigente da mobilidade, a que aludiu o padre Vieira: a comparação com a agricultura, sua forma produtiva e o tipo dos gêneros.

A própria Natureza singular do ouro extraído nas Minas Gerais, relacionada à história do seu descobrimento, denotando valores morais, não deixa de influir na gênese social. No texto, Antonil faz sugerir que a corrupção natural, social, racial - a forma do esquema interpretativo da significação das Minas —, estava sintetizada no ouro "preto" (o "branco" era mal formado) que, no entanto, era o mais cobiçado; portanto atinava-se com uma associação significativa, projetada do mundo colonial, entre uma condição racial e as atitudes morais que lhe seriam próprias ${ }^{46}$ Condizente com a Natureza de enganos do ouro preto (ou "mulato"), Antonil contou que o descobrimento (considerado fortuito) foi obra de "um mulato", um anônimo companheiro dos sertanistas paulistas apresadores de índios que, brutos (ou demonizados), ${ }^{47}$ obedeciam somente à lei do sertão, como supunham os representantes da Metrópole, especialmente na Bahia da época.

Com efeito, mais uma vez nota-se no jesuíta a lógica da correspondência originária entre os objetos da Natureza, expressões simuladas e ásperas, e a gente mineradora mestiça e embrutecida. Isso era o contrário do que supunha acontecer na lavra do açúcar, onde o produto de maior valor — o açúcar "branco macho" - produz-se, segundo Antonil, conforme a natureza expressiva da droga, com a perfeita purgação que se dava na parte de cima da forma. Isso "porque também nesta droga há sua nobreza [o branco], há casta vil [o pardo], há mistura". ${ }^{48}$ Mas, nas Minas do ouro, o mundo devia parecer-lhe mesmo de cabeça para baixo.

A História da América portuguesa desde o ano de 1500 do seu descobrimento até ao de 1724, obra mais famosa de Sebastião da Rocha Pita, cuja escrita terminou em meados da década de 1720 , foi impressa pela primeira vez em Lisboa no ano de 1730. O autor morreria oito anos depois na cidade de Salvador, tendo sido ali contemporâneo do padre Antonil. O seu nascimento ocorreu também na Bahia, em 1660. 
O baiano Rocha Pita foi coronel do regimento privilegiado de ordenanças, vereador (algumas vezes entre 1687 e 1721), juiz ordinário, fidalgo e cavaleiro da ordem de Cristo. Estudou no Colégio dos Jesuítas da Bahia, e talvez não tenha chegado a graduar-se bacharel na Universidade de Coimbra, como pretenderam alguns comentadores. Foi membro supranumerário da Academia Real de História Portuguesa, criada em 1720 por D. João V, e um dos associados fundadores de congênere colonial, a Academia Brasílica dos Esquecidos, formada em $1724 \mathrm{sob}$ o patrocínio do vice-rei. Herdeiro de títulos e bens familiares no Recôncavo, o senhor de engenho Rocha Pita, da nobreza da terra, foi ao mesmo tempo um beneficiário do poder do Estado, exercendo funções administrativas e militares na cabeça política do domínio luso da América. ${ }^{49}$ Fortuna familiar e poderio político estiveram ao seu alcance para sustentar quaisquer pretensões de letrado prestigioso, poeta e historiador.

O amparo régio com a fundação da Academia Real, que visava substituir o mecenato particular na escrita historiográfica, passaria a conceder o abono público da fidedignidade e da verdade do que se queria contar. Assim, não teria sido mero louvor bajulatório a dedicatória da História de Rocha Pita ao Rei João V. Reproduzindo o método tradicional da historiografia portuguesa desde o século XVI, o autor revelou, nas Advertências que abrem a obra, a sua busca de fontes fidedignas ou de testemunhos de pessoas confiáveis para compor a História, "cujo essencial instituto é a verdade". Supôs ter seguido o estilo histórico, parece que referindo-se ao relato cronológico dos fatos naturais e sociais tomados das fontes, mas com a representação da vivacidade do testemunho direto..$^{50}$

A pretensão de Rocha Pita de ter escrito a primeira História do Brasil aparece assinalada no Prólogo, justificando ao mesmo tempo a empreitada e o reconhecimento para si e para o texto. O valor da obra deveria depreenderse ainda mais do grande valor do objeto focalizado, isto é, o Brasil. Daí o fato de, nos dois primeiros livros da História, apreciar a Natureza e a terra - ou o "teatro" dos acontecimentos a serem narrados — com muitas louvações. Dentre as capitanias do Estado do Brasil (14 "províncias" quando o autor escreveu o livro), a Bahia destaca-se, com a sua terra e os agentes poderosos da colonização luso-brasileira. Além, talvez, de um nativismo latente de nobreza da terra, a louvação derramada de Rocha Pita parece seguir o critério de apreciação da legitimidade da própria obra historiográfica.

A História compõe-se ao todo de dez livros. Segue, de maneira geral, o padrão tradicional de narrativa e organização temática, encontrado em outros tratados das coisas do Brasil, nos séculos XVI e XVII. ${ }^{51}$ O primeiro livro 
detém-se na descrição do "corpo natural e material" do Brasil litorâneo (localização geográfica, costas, regime dos ventos e dos mares, condições ambientais, climáticas, topografia, hidrografia, flora, fauna e costumes indígenas), segundo o procedimento convencional nos séculos XVI e XVII que remontava a autores clássicos como Aristóteles e Plínio (Historia natural). ${ }^{52}$ Começando pela Bahia, o segundo livro aborda a organização civil, eclesiástica e militar das capitanias, desde o Pará até São Vicente; destaca ainda as produções econômicas, especialmente as que se inseriam no mercado atlântico - açúcar, tabaco, couramas e couros, ouro, drogas diversas e madeiras. A partir do terceiro livro, a narrativa da História de Rocha Pita toma como referência temporal a cronologia dos governos gerais do Estado do Brasil (relacionando também o governo eclesiástico), sediados em Salvador, e da sucessão real, assinalado-os comumente, como era o gosto dos letrados da época, com panegíricos.

Cabeça natural e política do Estado português no Novo Mundo (não acontecendo somente por escolha, mas graças à imposição da Natureza, superior à dos outros locais), interessou a Pita descrever sobretudo a Bahia, expressão brasílica do locus amoenus clássico,

onde prodigamente profusa a natureza se desentranha nas férteis produções, que em opulência da monarquia e benefício do mundo apura a arte, brotando as suas canas espremido néctar, e dando as suas frutas sazonada ambrosia, de que foram mentida sombra o licor e vianda que aos seus falsos deuses atribuiu a culta gentilidade. ${ }^{53}$

A rudeza quando se apresentava, nas disposições interiores da terra, não deixaria de ser maravilhosa pela beleza advinda da diversidade de formas serras, vales, campos, rios, lagoas e bosques. Mas, tal rudeza natural pareceria mais específica dos distritos das Minas do ouro, no sul do Brasil. ${ }^{54}$ Rocha Pita, desse modo, associou, a partir da interpretação antiga da condição geológica de terras montanhosas, a ocorrência das "inacessíveis serranias" às jazidas minerais. Não é à toa que, na História da América portuguesa, quando se tratou de indicar montes ou serras, atentou-se aos minerais.

Evidentemente, o fato notável na América portuguesa, testemunhado por Rocha Pita, foi o descobrimento das minas de ouro. Na explicação sobre a origem do ouro, o historiador considerou a junção entre a hipótese tradicional erudita e a história bíblica da criação do mundo: 
Gerou o sol nos embriões da terra do Brasil a profusa cópia de oiro que a natureza teve escondida imenso tempo, para sair com numerosos e riquíssimos partos no fim do século dezessete da nossa redenção, e cinqüenta e oito da criação do mundo, podendo ser mais antiga que a do gênero humano a [criação] deste precioso metal, pois sendo operação do príncipe dos planetas, que Deus criou no quarto dia, desde logo poderia (existindo o seu vigor nos seus atos) produzir os seus efeitos dois dias antes do sexto, em que o Senhor fez o homem. ${ }^{55}$

Já que as escrituras sagradas silenciavam sobre a criação dos minerais no subsolo, dificuldade teológica lembrada por Antônio Vieira, Rocha Pita, sob um prisma aristotélico, supunha como outros de sua época que o sol seria a causa eficiente, e acidental, da formação dos veios auríferos. Parece certo que nesse passo sobre a criação das veios minerais das Minas do Sul o historiador fundamenta-se em concepções muito antigas, validadas pelo naturalismo erudito do Renascimento, sobre o papel dos astros no engendramento das rochas e dos metais na terra e a semelhança destes com as plantas e os animais. ${ }^{56} \mathrm{~Pa}$ ra essa teoria, os minerais teriam vida, e até mesmo consciência, e originaram-se, assim como as plantas, de sementes que sofreriam uma maturação. Como conseqüência chegou-se a supor a ocorrência das jazidas auríferas como uma árvore de ouro, com os filões ou veios da mina sendo os galhos dessa árvore única, cujo tronco entranhava-se nas profundezas do subsolo. ${ }^{57}$ No século XVI, o escritor jesuíta José Acosta refere-se mesmo à difusão na América espanhola de certa teoria que via as ocorrências minerais como galhos de uma grande árvore rochosa cuja raiz devia ser a parte mais rica ${ }^{58}$ Da parte do historiador da América portuguesa, afinal a demora dos coloniais para chegar às minas não teria sido em vão: o ouro "tanto mais puro saiu. As pedras preciosas que mais se detêm em madurar nas minas, saem mais perfeitas; [assim como] as árvores que mais se demoram na produção dos frutos, os dão mais excelentes". ${ }^{59}$

Mas Rocha Pita parece sugerir outro problema: as terras minerais, notadamente as que escondiam ouro (que tinha o astro-rei como segunda causa), não trouxeram implicações para o gênero humano? A questão é relevante na medida em que, como se viu, a Natureza compunha uma ordem cosmológica, um conjunto de coisas cujas relações e correspondências obedeceriam ao complexo modelo de causalidades e influências recíprocas. Do cosmo ao microcosmo humano não havia descontinuidade, mas tudo fazia parte de um mesmo campo de forças, aberto até mesmo para os recursos da magia. Sérgio Buarque de Holanda enfatizou a existência nos séculos XVI e XVII de uma vi- 
são tradicional muito positiva dos metais e das gemas preciosas, baseada nessa concepção cosmológica: "As extraordinárias propriedades de que seriam dotados proviriam de uma espécie de rescaldo de sua intimidade com o Céu”. ${ }^{60}$

A princípio, e fatalmente, o corpo social apresentava-se marcado pelos sucessos astrológicos. Quando, na Bahia, depois do aparecimento de um temível cometa, houve um aumento surpreendente da maré, deixando depois na vazante muitos peixes pelas praias, Rocha Pita interpretou aquilo como um mau presságio, pois "quando saem da ordem natural os corpos elementais, padecem os humanos, e causam não só mudanças na saúde e ruínas nas fábricas materiais, mas nos impérios" ${ }^{16}$ Confirmou-se posteriormente o prognóstico, com o surgimento no Brasil de uma epidemia de varíola. ${ }^{62}$

Contudo, para o historiador baiano, sobre a vida e a condição humanas não incidiam somente certas disposições do céu ou ação vital dos planetas, mas também o "clima". Ao tratar do talento de Antônio Vieira e das influências que teria recebido para a sua formação, observou que "se deve tanto a Portugal pela felicidade do horóscopo em que nasceu, como ao Brasil pela influência do clima em que se criou; se teve neles mais domínio a força do planeta que o poder da educação; problema ou ponto sobre que disputam muitos autores, mais a favor da criação que do nascimento". O clima, espécie de condição regional do mundo natural, tinha assim componentes pronunciados que eram de fabricação (ou da arte) humana. Por isso, ser natural, ou conforme a essa Natureza, significava conduzir-se pelas determinações do clima, meio constituído de elementos físicos, sociais e morais.

Pois assim vê-se que nesse nível do teatro natural podia (e devia) acontecer a ingerência humana, espaço cênico de atuação do Estado colonial. Isso produzia duas visões complementares, e só aparentemente contraditórias: a necessidade de ordenamento sistemático do Estado segundo virtudes políticas e religiosas e o realismo de um corpo sociopolítico moldado à natureza e aos costumes da terra. Rocha Pita, como homem de poder e governos, entende bem disso, e, à maneira de outros da época, sugere uma política colonial de bater e soprar nas Minas há pouco descobertas. Artur de Sá e Menezes, governador das Capitanias do Sul, não agiu corretamente; foi às Minas "mais como particular" e não exerceu "atos do seu poder e jurisdição", fez-se um igual aos seus súditos. O sucessor, Fernando Martins Mascarenhas de Lencastro, tendo sido mais correto, foi às Minas, mas mostrando-se parcial ("inclinação aos Paulistas" no conflito emboaba), não conseguiu impor o poder real. Já Manuel Nunes Viana (aliás com fortes laços com os poderosos da Bahia), eleito governador dos “povos das Minas" em luta contra os paulistas, mos- 
trou-se conciliador, perdoando e premiando, criando cargos militares, de justiça e da fazenda locais. O sucessor legítimo, Antônio de Albuquerque Coelho de Carvalho, esperado e requerido nas Minas, fez a composição dos partidos e parcialidades, administrado a justiça da Coroa. Para isso manteve o ordenamento dos cargos e de posições sociais do Estado conferido por Viana, criando ainda outras funções de acordo com o serviço real e o bem dos povos. Quando o Rei finalmente estabeleceu um governo autônomo para as Minas de ouro, escolhendo ainda Antônio de Albuquerque para chefiá-lo, logo este passou a reduzir os povos à condição de súditos, promovendo a "vida urbana e política" dos habitantes e dando forma à paisagem com ereção de vilas, jurisdições e limites ("uma nova república”).63

Mas, segundo Rocha Pita, graças à gama variada de gente que entrava para as Minas, resultando em "corpos mal complecionados" cujos membros mantinham-se "descompostos", seria necessária a ação prudente, e ao mesmo tempo enérgica, de outro governador, o conde de Assumar, para debelar motins que ali ocorreram contra os direitos régios (quintos) no ouro extraído. ${ }^{64}$ Num relato da época sobre esses motins que reuniram poderosos e populares, há uma descrição do clima das minas muito próxima daquela que parece convir ao historiador baiano e até mesmo ao padre Antonil: país sempre nublado, frio, com elementos naturais instáveis, habitado por gente revoltosa, e que sofre a influência desordeira dos astros; "o clima é tumba da paz e berço da rebelião; a natureza anda inquieta consigo, e amotinada lá por dentro, é como no inferno". ${ }^{65}$

\section{A TÍTUlo DE CONCLUSÃO}

Ao longo do século XVIII, tudo indica que se conservou a visão de Natureza turbulenta das Minas, mescla de explicações naturais e sobrenaturais, mas não nos escritos políticos (ou nos alvitres) que alertavam a necessidade de reforma econômica da região. A ingerência do governo régio, conformando o Estado colonial nas Minas preconizado por Antonil e Rocha Pita, apresentava-se bastante visível com o tempo. De modo geral, esses coloniais eruditos intentaram reduzir a Natureza e a história regionais ao raio de ação moral, político-jurídica e econômica dos agentes legítimos do Estado. $\mathrm{O}$ recurso das alegorias, prática de expressão simbólica do espaço, da topografia ou do clima das Minas de ouro, serviria bem ao papel. Mas o padre Antonil parece ter conservado, mais do que o historiador baiano, o comedimento, res- 
guardando-se de opiniões insensatas (ou pouco ortodoxas) sobre as Minas do Sul. A narrativa de Rocha Pita, movendo-se na fundamentação do fato histórico novo de tesouros minerais na América portuguesa, que impunha o confronto entre fontes eruditas e relatos, leva a noções ou adaptações talvez demasiadamente naturalistas para a época do barroco.

A descrição maravilhosa (vislumbrando ou não a dimensão demoníaca) das montanhas minerais, mesmo quando contida, manteve-se significativa nos meios populares pela conferência mútua entre a experiência pessoal e as narrativas tradicionais. No início da década de 1730, um informante de descoberto na serra do Sambê, sertão da capitania do Rio de Janeiro, revelou impressionado:

Nestes ribeiros, e rios, é que se tem achado ouro, e em os mais deles se experimentam uns efeitos sobrenaturais, como também por todos os arredores da serra em grande espaço, os quais a quem não tem notícia, ou experiência, assombra, pasma, e confunde, quais outros encantamentos nos tempos passados. No maior sossego da noite quando o tempo está mais claro, e sereno, é tanta a desinquietação das pedras umas com outras, que se forem lançadas com o impulso vigoroso de uma forçosa mão, não se poderão mal tratar tanto, nem fazer maior estrondo.

Observando que o tal descoberto ficava na mesma latitude das terras diamantinas nas Minas e apresentava o mesmo clima e aspereza, indícios seguros de pedrarias ocultas, ainda contou da dificuldade de uso de armas de fogo na serra, onde pareciam fugir ao controle e ao seu manuseio normal. Quando se disparava a arma, o tempo podia mudar de uma hora para outra, vindo uma tormenta de chuva, vento, trovões e relâmpagos. Os estrondos ouvidos seriam até maiores do que tiros de artilharia. ${ }^{66}$ No sertão baiano, outra serra, supostamente com minas de esmeraldas, era temida por índios topins por causa dos estrondos assustadores, e conforme o relato do vigário de Jacobina houve uma noite com estouros e vulcões de fogo, obrigando a gente de uma expedição a abandonar o lugar imediatamente. Era bastante comum notar rumor subterrâneo naqueles lugares que se supunha conter veios (e tesouros) minerais como Minas Gerais e Mato Grosso. E ainda no século XIX, viu-se o morro do Jaraguá do Planalto de São Paulo, há muito explorado, lançar chamas e fumaça. ${ }^{67}$ Houve também relatos que, atualizando e conjugando crenças populares tradicionais, descreviam seres prodigiosos vivendo nos recônditos montanhosos, como guardiães das riquezas encobertas. O padre Simão de Vasconcelos divul- 
gou as notícias de alguns desses habitantes monstruosos dos sertões da América no século XVII: anões, gigantes adornados de ouro, amazonas estabelecidas nas grandes montanhas. Em 1731, Lourenço de Almeida, governador da capitania de Minas Gerais, sem revelar espanto (ou dúvida) com os relatos, como se monstrengos ou exagerações naturais do tipo fossem próprias do clima, alegou seriamente que a extração de diamantes no rio Jequitinhonha abaixo estava comprometida por causa das "cobras de mais de trinta palmos de comprido, e tão grossas como um barril" que tinham engolido "alguns negros"; por isso, ninguém ousava mergulhar naquelas águas. ${ }^{68}$

\section{NOTAS}

${ }^{1}$ Mas vale ver a discussão sobre o anacronismo (romântico) de muitas das categorias de análise aplicadas às obras artísticas e literárias dos séculos XVII e XVIII que determinaram a construção conceitual do termo "barroco". HANSEN, João Adolfo. Notas sobre o "barroco". Revista do IFAC, n.4, dez. 1997, p.11-20.

${ }^{2} \mathrm{O}$ conceito de "Natureza" (natura) é muito complexo e a sua utilização variou conforme o ambiente sócio-cultural e político. Segui, neste artigo, certa tradição do pensamento cristão de Natureza, valioso para o enfoque proposto, que a define sob um ponto de vista teológico como o conjunto das coisas (naturais) criadas por Deus. Consultar, a este respeito, o verbete "Naturaleza" em MORA, José Ferrater. Diccionario de Filosofía. Madrid: Alianza Editorial, 1982. p.2309-14.

${ }^{3}$ Seguem-se as interpretações de Pécora sobre o pensamento vieiriano. PÉCORA, Alcir. Teatro do Sacramento: a unidade Teológico-Retórico-Política dos Sermões de Antônio Vieira. São Paulo: Edusp; Campinas: Ed. Unicamp, 1994.

${ }^{4}$ Cf. HOLANDA, Sérgio Buarque de. Raízes do Brasil. 24.ed. Rio de Janeiro: J. Olympio, 1992. p.99-100.

${ }^{5}$ BURKE, Peter. História como alegoria. Estudos avançados, v.9, n.25, 1995, p.201.

${ }^{6}$ Ver "Die Ganze Welt in Einem Kleberbat", de Heinrich Bünting, 1581; O tesouro dos mapas. A cartografia na formação do Brasil. São Paulo: Instituto Cultural Banco Santos, 2002. CD-rom.

${ }^{7}$ COSTA, Cláudio Manuel da. Vila Rica. Ouro Preto: Tipografia do Estado de Minas, 1897. p.94. Cf. GOMES, Plínio Freire. Um herege vai ao paraíso: cosmologia de um ex-colono condenado pela Inquisição (1680-1744). São Paulo: Companhia das Letras, 1997. p.116-7.

${ }^{8}$ GÂNDAVO, Pero de Magalhães. Tratado da terra do Brasil. 5.ed. Recife: Fundaj/Ed. Massangana, 1995. p.23; SOUZA, Gabriel Soares de. Notícia do Brasil. São Paulo: MEC, 1974. p.98. 
${ }^{9}$ GÂNDAVO, Pero de Magalhães. História da província Santa Cruz a que vulgarmente chamamos Brasil. 12.ed. Recife: Fundaj/Ed. Massangana, 1995. p.73. Na História, publicada em Lisboa, foi retomado e ampliado o texto do Tratado da terra do Brasil, mas naquela obra a alegorização da banana — o fruto que anunciava a crucificação do filho de Deus - desapareceu.

${ }^{10}$ Holanda retraça a analogia proposta por Frei Antônio do Rosário (1702) sobre o ananás: “Assim, se a rosa tem coroa, púrpura, trono, e guarda real para representar na cor os mistérios gozosos, nos espinhos, os dolorosos e na gala, os gloriosos, no mundo novo fez Deus o ananás com o mesmo estado e aparato real de coroa, cetro, púrpura, guardas (espinhos), para que o rosário de sua mãe fosse o fruto, que no mundo velho era a flor”. HOLANDA, Sérgio B. de. Visão do paraíso: os motivos edênicos no descobrimento e colonização do Brasil. 6.ed. São Paulo: Brasiliense, 1994. p.238-9, 241-2.

${ }^{11}$ Ibidem, p.61-6.

12 "Os acontecimentos, coisa ou personalidade histórica [tipos] referidos ligam-se a outros, futuros, através de uma significação comum. Sua intersecção, como demonstra Auerbach, é de natureza conceitual”. HANSEN, João Adolfo. Alegoria: construção e interpretação da metáfora. 2.ed. São Paulo: Atual, 1987. p.50.

${ }^{13}$ Cf. CURTO, Diogo Ramada. O discurso político em Portugal (1600-1650). Lisboa: Centro de Estudos de História e Cultura portuguesa, 1988. p.30.

${ }^{14}$ HANSEN, op. cit., p.99. Os capítulos 3 e 4 foram fundamentais para este artigo.

${ }^{15}$ Voz de Deos, ao Mundo, a Portugal, \& à Bahia. In: Sermões do Padre António Vieira. São Paulo: Ed. Anchieta, 1945. p.259-60. O sermão foi proferido em 1695.

${ }^{16}$ PÉCORA, op. cit., cap.5.

${ }^{17}$ Ibidem, p.241.

${ }^{18}$ VIEIRA, Padre Antônio. Sermões. Organização e introdução Alcir Pécora. São Paulo: Hedra, 2000. p.563-89. Para uma análise detida do sermão sobre as minas, ANDRADE, Francisco Eduardo de. A invenção das Minas Gerais: empresas, descobrimentos e entradas nos sertões do ouro (1680-1822). São Paulo, 2002. (Tese, Doutorado em História) FFLCH/USP. cap.4.

${ }^{19}$ Sobre a noção de incidente (ou acidente) da Natureza, no século XVII, tratando das diferenças de cor entre as gentes coloniais, ver BRANDÃO, Ambrósio Fernandes. Diálogos das grandezas do Brasil. Rio de Janeiro: Dois Mundos, 1943. p.101.

${ }^{20}$ BOURDIEU, Pierre. O poder simbólico. Trad. Fernando Tomaz. Rio de Janeiro: Bertrand Brasil, 1998. p.145.

${ }^{21}$ Bourdieu esclarece, referindo-se à construção regional: “O discurso regionalista é um discurso performativo, que tem em vista impor como legítima uma nova definição das fronteiras e dar a conhecer e fazer reconhecer uma região assim delimitada — e, como tal, 
desconhecida - contra a definição dominante, portanto reconhecida e legítima, que a ignora". Cf. ibidem, p.116.

${ }^{22}$ LEITE, Serafim. História da Companhia de Jesus no Brasil. Rio de Janeiro: INL, 1949. t.8, p.45. O mais completo estudo crítico de Cultura e opulência é seguramente o de Andrée Mansuy Diniz Silva, resultado de uma análise profunda da obra de $1711 \mathrm{em}$ tese de doutoramento na Sorbonne. SILVA, Andrée Mansuy Diniz. Introdução. In: ANTONIL, André João. Cultura e opulência do Brasil por suas drogas e minas. Lisboa: Comissão Nacional para as Comemorações dos Descobrimentos Portugueses, 2001. 1.ed. portuguesa. Outro estudo muito importante sobre a obra é o de CANABRAVA, Alice P. "João Andreoni e sua obra”. In: ANDREONI, João Antônio (André João Antonil). Cultura e opulência do Brasil (texto da edição de 1711). 2.ed. São Paulo: Cia. Ed. Nacional, 1967. Neste artigo geralmente segui os comentários de Andrée Mansuy. Além disso, todas as referências ao texto de Antonil são relativas à edição portuguesa.

${ }^{23}$ Ibidem, p.15-6. Ver SILVA, op. cit., p.226, nota 2.

${ }^{24}$ Ibidem, p.27-9.

${ }^{25}$ CANABRAVA, op. cit., p.35-6.

${ }^{26}$ SILVA, op. cit., p.38-43.

${ }^{27}$ Ver último capítulo de ANTONIL, op. cit., p.334-5.

${ }^{28}$ Andreoni parece distanciar-se de Vieira de maneira cabal pelo menos desde 1690, motivado por divergências sobre o governo da Província dos jesuítas no Brasil. BOSI, Alfredo. Dialética da colonização. 3.ed. São Paulo: Companhia das Letras, 1992. p.154-7. Estes conflitos foram interpretados como fundamentados no embate entre duas concepções díspares e necessariamente excludentes: uma teológica e moral (medieval) — a de Vieira —, e a outra econômica e mercantil (moderna) - a de Andreoni e de outros padres estrangeiros da Companhia, como o italiano Jorge Benci. Isso é problemático, pois além de poderem coexistir num mesmo autor ou sujeito, entrecruzando-se, deixam de lado o fato de que as concepções pragmáticas (como a escravização do bárbaro/indígena, por exemplo) se valiam de justificativas que, desde os antigos, encontravam-se em alguns escritores medievais respeitáveis. No início do século XVI, há mesmo com Frei Bernardo de Mesa, da ordem dos Predicadores, uma acomodação bem escolástica das opiniões contrárias sobre a capacidade (racional e livre) do índio do Novo Mundo para receber a fé: a dignidade racional do índio da qual se nutria a liberdade cristã, agravada por causas da Natureza e costumes viciosos, devia exigir algum tipo de servidão indígena para conservação da fé e constrangimento dos costumes. Cf. ZAVALA, Silvio. La filosofia política en la Conquista de América. México: Fondo de Cultura Económica, 1972. p.50, 56, 73-5. Parece-me que a administração indígena por conta dos paulistas, no final do século XVII, baseava-se num acordo jurídico e teológico do gênero.

${ }^{29}$ Ibidem, p.311. 
${ }^{30}$ Cf. CANABRAVA, op. cit., p.38-9.

${ }^{31}$ Cf. SOUZA, Laura de Mello e. O diabo e a Terra de Santa Cruz: feitiçaria e religiosidade popular no Brasil colonial. São Paulo: Companhia das Letras, 1986. p.72-85.

${ }^{32}$ ANTONIL, op. cit., p.183. O mesmo Antonil não deixa de reproduzir a metáfora, divulgada por Vieira em 1633 (confere Andrée Mansuy em nota crítica), de que os engenhos devido às fornalhas das caldeiras e tachas eram como o Inferno - um doce inferno. Mas, o capítulo conclusivo da parte relativa ao açúcar no Cultura e opulência não deixa dúvida de que, para Antonil, o fim de todo o processo de fabricação, o sentido último que merece realçar, é a transformação do açúcar com o seu conseqüente comércio ("E ainda assim, sempre doce e vencedor de amarguras, vai a dar gosto ao paladar dos seus inimigos.... Cf. ibidem, p.135-6, 185.

${ }^{33}$ Ibidem, p.246, 258-62.

${ }^{34}$ Ibidem, p.242-9.

${ }^{35}$ KOSHIBA, Luís. A honra e a cobiça. São Paulo, 1988. (Tese, doutorado em História) FFLCH/USP. p.163-9.

${ }^{36}$ SCHAMA, Simon. Paisagem e memória. Trad. Hildegard Feist. São Paulo: Companhia das Letras, 1996. p.413-25.

${ }^{37}$ A suposta objetividade de Antonil, baseada numa razão mercantil, significa que ele teria mostrado as forças que necessariamente regeram a experiência colonial mercantilista. Cf. BOSI, op. cit., p.158; CANABRA, op. cit., p.33.

${ }^{38}$ ANTONIL, op. cit., p.281-2. Mas, segundo Antonil, o intercâmbio com as Minas seria bem mais fácil do lado baiano do que nas rotas paulista e carioca, em virtude das condições naturais e de abastecimento largamente favoráveis, e esse fato parece corroborar a maior legitimidade do comércio mineiro com a Bahia. Ibidem, p.298. Não resta dúvida de que a defesa da boa natureza do caminho convinha ao jogo político e de interesses socioeconômicos.

${ }^{39}$ Cf. HOLANDA, op. cit., p.33. Em 1732, o secretário do Governo da Capitania de Minas Gerais, Manuel Afonseca de Azevedo, descreveu em cores vivas o quadro do trabalho e dos jornais de escravas e forras das Minas, resultado do "pouco temor de Deus e desordenada ambição que, no País das Minas, é e foi sempre a Capitania de todos os negócios”. Apud BARBOSA, Waldemar de Almeida. Negros e quilombos em Minas Gerais. Belo Horizonte: Imprensa Oficial, 1972. p.120-3.

${ }^{40}$ Ver, a respeito, ARAÚJO, Emanuel. O teatro dos vícios: transgressão e transigência na sociedade urbana colonial. 2.ed. Rio de Janeiro: J. Olympio, 1997.

${ }^{41}$ ANTONIL, op. cit., p.252.

${ }^{42}$ Ibidem, p.299. Era tradicional nos meios cultos europeus fazer descrições de paisagens montanhosas que conjugavam aspereza e esterilidade naturais, rusticidade de montanhe- 
ses e expressões de medo do descritor. THOMAS, Keith. O homem e o mundo natural. Mudanças de atitude em relação às plantas e aos animais (1500-1800). Trad. João R. Martins Filho. São Paulo: Companhia das Letras, 1988. p.306-7.

${ }^{43}$ Deve-se confrontar o capítulo 8 com o "capítulo último", que é conclusivo na parte do livro relacionada às Minas.

${ }^{44}$ Ibidem, p.254-7. "Convidou-os [aos mineradores de cabedal] o ouro a jogar largamente e a gastar com superfluidades quantias extraordinárias sem reparo, comprando (por exemplo) um negro trombeteiro por mil cruzados, e uma mulata de mau trato por dobrado preço, para multiplicar com ela contínuos e escandalosos pecados”. Ibidem, p.310.

${ }^{45}$ Ibidem, p.177, 257, 311. Na realidade, a proibição do caminho do sertão da Bahia e do embarque de escravos para o Rio de Janeiro não conseguiu o intento propalado de estancar as rotas por meio das quais afluíam os escravos e outras mercadorias enviadas do Recôncavo e de Pernambuco. Cf. SILVA, op. cit., p.40-1. Embora houvesse interesse em manterem-se vinculados à economia açucareira, senhores de engenho e negociantes do Recôncavo baiano ganharam com o comércio para as Minas e a exploração do ouro. O jogo real desses homens era apostar nas possibilidades daquelas economias coloniais quando as oportunidades de lucro se apresentavam, pois os fluxos econômicos e mercantis eram marcadamente instáveis. Por isso, Antonil parece, no sentido geral da obra, também exortar os senhores, os lavradores e os negociantes da Bahia para persistirem no papel prestigioso que vinham desempenhando, cujo significado devia ser bem mais do que propriamente econômico ou lucrativo, mas sociopolítico e missionário (religioso).

${ }^{46}$ ANTONIL, op. cit., p.239. Deram-se, em textos coevos, outras designações significativas a esse ouro extraído nas Minas Gerais: "mulato" ou ainda "podre".

47 "Animalização e demonização andaram de braços dados". VAINFAS, Ronaldo. Trópico dos pecados: moral, sexualidade e inquisição no Brasil. Rio de Janeiro: Campus, 1989. p.20.

${ }^{48}$ ANTONIL, op. cit., p.171.

${ }^{49}$ CALMON, Pedro. Introdução. In: PITA, Sebastião da Rocha. História da América portuguesa. Belo Horizonte: Itatiaia; São Paulo: Edusp, 1976. p.12; Idem. História da literatura baiana. 2.ed. São Paulo: J. Olympio, 1949. p.53-4; DANTAS JÚNIOR. Rocha Pita. Salvador: Publicações da Universidade da Bahia, 1960, p.17-8; RODRIGUES, José Honório. História da História do Brasil. Historiografia colonial. 2.ed. São Paulo: Cia. Ed. Nacional, 1979. p.494-5.

${ }^{50}$ Ibidem, p.496.

${ }^{51}$ Para um confronto exemplar, vale conferir os temas dos livros (ver especialmente os dois primeiros) que compreendiam a História do Brasil de Frei Vicente do Salvador, obra do início do século XVII.

${ }^{52}$ Para uma discussão esclarecedora, ver SALAZAR-SOLER, Carmen. Construyendo teorías: saber de los “Antiguos” y saber indígena en el Perú de los siglos XVI e XVII. Passar as 
fronteiras. Actas do II Colóquio Internacional sobre mediadores culturais. Séculos XV a XVIII. Lagos: Centro de Estudos Gil Eanes, 1999.

${ }^{53}$ PITA, Sebastião da Rocha. História da América portuguesa. Belo Horizonte: Itatiaia, São Paulo: Edusp, 1976. p.19. Cf. HOLANDA, op. cit., p.293-4; AINSA, Fernando. De la edad de oro a el dorado. Génesis del discurso utópico americano. México: Fundo de Cultura Económica, 1992. p.85-7.

${ }^{54}$ PITA, op. cit., p.21-2.

${ }^{55}$ Ibidem, p.221.

${ }^{56}$ Para manter-se fiel à idéia do sol como o móvel gerador dos minerais, Rocha Pita desviou as grandes minas descobertas (do Ouro Preto e das Minas Gerais) para debaixo do trópico de Capricórnio ("vinte e três graus e meio"), altura na qual haveria, mais do que nas proximidades do Equador (parte mais "nobre” do Céu segundo o padre Simão de Vasconcelos), segundo uma concepção comum, maior duração dos efeitos solares de luz e calor. Cf. HOLANDA, op. cit., p.289-93, 363-5 (Anexo).

${ }^{57}$ LENOBLE, Robert. Esquisse d'une histoire de l'idée de Nature. Paris: Albin Michel, 1969. p.295-6.

${ }^{58}$ Cf. ANDRADE, op. cit., p.143.

${ }^{59}$ PITA, op. cit., p.221.

${ }^{60}$ HOLANDA, op. cit., p.202.

${ }^{61}$ Ibidem, p.169-70.

${ }^{62}$ Rocha Pita não se apresenta tão escolástico quanto somos levados a crer num primeiro momento, sua atitude atenta frente aos milagres e aos acontecimentos fantásticos para denunciar a manifestação maravilhosa da Natureza acaba esmaecendo a figura poderosa do Deus criador. Cf. LENOBLE, op. cit., p.292-5, 300.

${ }^{63}$ PITA, op. cit., p.223, 242-7. Rocha Pita, como Antonil mais de uma década antes, via as Minas do ouro a partir dos interesses baianos e açucareiros, salientando a ruína do Brasil, e particularmente dos núcleos açucareiros, com a ambição dos colonos e com os preços abusivos causados pelas descobertas das Minas (reproduz a antiga máxima de que o açúcar é "a maior manufatura e interesse do Brasil, com a qual chegara a tão grande nome e opulência todo o Estado"). No entanto, tudo indica que, ciente da relativa permanência daqueles descobertos e da instalação do governo metropolitano naqueles sertões, o historiador procurou debitar a verdadeira experiência colonizadora - a extração duradoura do ouro das serras e a instituição de um governo justo, aquele de Manuel Nunes Viana aos baianos e aos reinóis (os emboabas vitoriosos), que, na verdade, disputavam os lucros das rotas do Império atlântico que buscavam as Minas. Para ele aconteceu o que para Antonil ainda era uma potencialidade: o governo legítimo do Estado (através da autoridade de Antônio de Albuquerque) realmente vem corrigir a condição social corrompida e a disposição natural, marcada por certa influência danosa. Ibidem, p.232. 
${ }^{64}$ Trata-se, em especial, da famosa revolta que levou à execução sumária do tropeiro (e comediante) português Felipe dos Santos Freire. Ibidem, p.274-6. Cf. CARVALHO, Teófilo Feu de. Ementário da História de Minas. Felipe dos Santos Freire na sedição de Vila Rica 1720. Belo Horizonte: Ed. Históricas, s.d.

${ }^{65}$ DISCURSO histórico e político sobre a sublevação que nas Minas houve no ano de 1720. Belo Horizonte: Fundação João Pinheiro/Centro de Estudos Históricos e Culturais, 1994. p.59.

${ }^{66}$ Arquivo do Instituto de Estudos Brasileiros - IEB/USP, códice 67.3, Extrato feito sobre a povoação dos Campos novos, e suas utilidades, e dos descobrimentos de ouro, e pedras verdes da serra do Sambê.

${ }^{67}$ Carta do coronel Pedro Barbosa Leal ao Conde de Sabugosa ... [22.11.1725]. Documentos interessantes para a história e costumes de São Paulo, São Paulo, v.48, 1929, p.92-3; RICARDO, Cassiano. Marcha para oeste. São Paulo: J. Olympio, 1940. v.2, p.63-4.

${ }^{68}$ TAUNAY, Afonso d'E. Monstros e monstrengos do Brasil. Revista do Museu Paulista, São Paulo, t.21, 1937, p.964-5. Arquivo Público Mineiro, seção colonial, códice 23, f. 185v. 